\title{
The Rise of Stalin's Personality Cult in Soviet Belarus
}

\author{
BY \\ ALIAKSANDR HUŽALOǓSKI \\ As soon as a certain number of living beings are gathered together, \\ whether they be animals or men, they place themselves instinctively \\ under the authority of a chief. \\ Gustave Le Bon
}

\section{Introduction}

Josef Stalin left behind a difficult and traumatic legacy. The cult of his personality played an important role in the political and cultural history of Soviet Belarus. From 1929 until 1953 the media presented the dictator as an all-powerful, all-knowing leader and his image became omnipresent: his leadership mutilated a Belarusian society already traumatised beyond recognition by wars and revolutions. His image still exists in the collective memory of Belarusians. Two waves of deStalinisation, in the 1950s and 1990s respectively, didn't leave much Belarusian scholarly writing on the subject (Kostjuk 2002, 139; Platonaŭ 1996, 5; Prot'ko 2002, 85). However, the traumatic historic events, or processes, left their mark on the collective subconscious and manifest themselves in a negative way in the contemporary life of both society as a whole and individuals.

While not claiming to provide an in-depth analysis of the Stalin's cult of personality per se, this paper attempts to clarify the previously neglected issue of the personality cult's genesis in the late 1920s and early 1930s in Soviet Belarus.

To do this, this article comprises four parts. The first discusses the issue of cult construction by means of Communist Party propaganda tools such as everyday political education and its various political campaigns. The discussion in the second section turns to the process of forming the dictator's cult by means of literature and art, and is divided into two subsections: the first presents an overview of Stalin's rise as a dominant figure in poetry; the second subsection traces how the image of Stalin was introduced in Soviet Belarusian art. The third part shows how the bonds between Stalin and the population of the Republic have been manufactured through 
place names. The fourth and final part analyses the resistance to the establishment of Stalin's cult of personality in Soviet Belarus.

Research on Stalin's cult of personality is extensive and encompasses a wide number of academic disciplines, including history, political science, psychology, sociology, film, music, literature and the visual arts. International scholars discuss the origins of the cult, its hierarchies, reception, export and dismantling, as well as its associated thoughts, practices and images. The first insight into the phenomenon of the cult of Stalin was given by contemporary critics of his regime (Trotsky 1990, 136-213). It was generally accepted by Kremlinologists that the cult of Stalin was a central element of Stalinism, an integral part of his power, and as such it was one of the most salient features of Soviet civilisation (Friedrich and Brzezinski 1965). Parallel to this a new understanding of the personality cult was beginning to be developed by other humanities scholars.

A vast array of material has been published on the historical, political and social conditions in the USSR under Stalin. Key texts dealing with his cult of personality include those written by political historians (Ennker 1998, 151-182; Gill 1980, 167-86; Morgan 2017; Rees 2004, 3-28; Rolf 2004, 141-160), art historians (Pisch 2016; Plamper 2010), social historians (Stepper and Suppan 2000, 286305), historians of childhood (Kelly 2005, 199-224), literary historians (Sobanet 2018), and political psychologists (Post 1986, 675-88). The first solid research works with an emphasis on the cult's regional dimension enriched international studies of the Soviet Union's totalitarianism (Ashirova 2009).

It has been argued by sociologists that the cult concept should be placed in a broader person-centred social and cultural context. In his study on Weber's concept of charismatic authority, Joshua Derman provides a holistic tool with which one can analyse leaders such as Stalin from a new perspective (Derman 2012, 180). More importantly, it creates the foundation for more objective interpretations of authoritarian leaders' cults as an instrument for the legitimisation of their rule. Stalin's rule can be understood within Weber's charismatic legitimation type. On the other hand, the political leader cult, rooted deeply in the Belarusian patriarchal society, might be looked at through Serge Moscovici's optics of the "father archetype". The interpretation of one of the major Jungian archetypes in the 'age of the crowd' disclosed its most primordial function to promote discrimination of opposites. (Moscovici 2011, 176).

\section{The Stalin Cult and the Party's Propaganda Media}

Jan Plumper, who provided a sound methodology for examining the images of Stalin, noted that the emergence of the cult was accompanied by no regulations or 


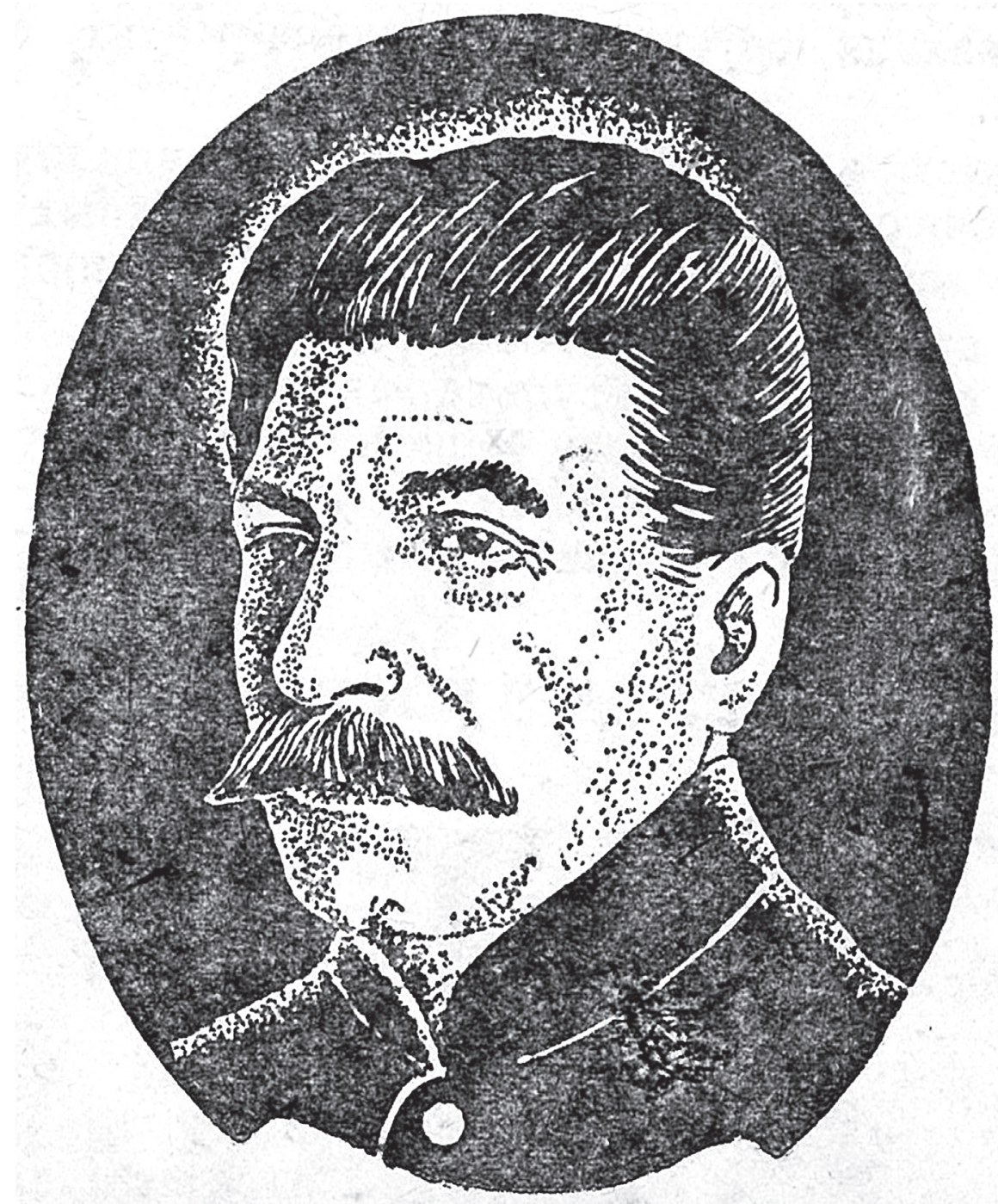

Figure 1: Henadz Zmudzinski. “Comrade Stalin”. Graphics, 1932.

“A woman worker and a woman farmer”, 1932, № 17, p. 3. 
special structures (Plamper 2010, 14). With tacit consent, or personal involvement of the dictator, his cult was gradually constructed by the Communist Party propaganda departments with the assistance of the media, literature, art, place names and oral propaganda.

The Secretary of the Communist Party (Bolsheviks) of Belarus's Central Committee (TsK KP(b)B) on Ideological Work was by default in charge of general cult management. In the mid-1930s the Department of Propaganda and Agitation of the Central Committee numbered 34 personnel and was subordinate to the secretary, performing routine managerial work towards the construction of the Stalin cult. The Department of Propaganda and Agitation staff was assisted by 719 propagandists who worked in regional ("oblast" and "rajon") offices. All newspapers, magazines, radio stations, publishing houses, and cultural or educational institutions, as well as the facilities of Marxist-Leninist training, were under the direct supervision of the propaganda structures (Nacyjanaĺny archiŭ Respubliki Bielaruś (NARB), f. 4p, vop. 1, spr. 12948, ark. 159).

The largest division of the Department of Propaganda and Agitation was the print sector, reflecting the major role played by print media in the ideological impact on the population. Placed under the total control of the print sector department, Soviet Belarusian newspapers lost their individual character and became a mouthpiece for Stalinist propaganda; this can be seen even in their names. ${ }^{1}$

The first representation of Stalin as one of the state leaders in the Belarusian media dates back to December 1925 when he first addressed the 14th AllUnion Party Congress with a political report (Politichesky otchet TsK 1925, 1). Accordingly, a new ritual emerged in the Soviet national communist parties in the form of a collective greeting to Stalin and promises to maintain political unity. The Belarusian communists greeted the General Secretary for the first time at their 9th Congress in Minsk in December 1925 (NARB, f. 4p, vop. 1, spr. 1983, ark. 40). However, during the second half of the 1920s Stalin's portraits still appeared on the pages of Belarusian periodicals only in connection with important political events.

It is hard to pinpoint precisely when the cult took on a life and momentum of its own. The year 1929, which marked the beginning of "revolution from

\footnotetext{
' By the early 1950s, in addition to the republican newspaper "'Stalinskaja molodjezh' (molodjezh" ("Stalin's youth),"), newspapers titled 'Stalinets' ("Stalinets" ("Follower of Stalin)") were published in the towns of Arechava, Biešankovičy, Vietryna, Hresk, Domačava, Dobruš, Žuravičy, Mikaševičy, Orša, and Smarhon; "Stalinskaja Pravda" ("Stalin's truth"))") newspapers were published in Antopal, Astraviec, Vietka, Kličaŭ, Pietrykaŭ, Rudensk; "Stalinskij prizyv" ("Stalin's call)") newspapers were printed in the towns of Jezeryšča, Zeĺva, Kastiukovičy, Kochanava, Svislač; "Stalinskij marshrut" ("Stalin's route)" was the title of the Minsk and Baranavičy railway administration newspapers; "Stalinsky flag" ("Stalin's flag") published in Homieí, Kosava, Naroŭlia, Navajeĺnia, Šarkaǔščyna, Šumilina, Juracišky; and "Stalinski šliach" ("Stalin's way") was printed in Bahušeǔsk, Ivanava, Kličaŭ, MaladziečnaMaladzečna, Polack, Sapockin, Śvir, Strešyn, Čavusy. The most poetic name "Stalinskie vschody(“(Stalin's shoot") was invented for its newspaper by the political department of a machine-tractor station in the town of Masty.
} 
above," ${ }^{2}$ was in many ways more of a watershed than the year 1917. In an article specially dedicated to this year, Stalin described it as the year of the "Great Break," referring primarily to the beginning of accelerated industrialisation and forced collectivisation. Alongside the dramatic changes in economic development the year of 1929 also witnessed the intensification of Communist Party mass propaganda, changes in the social structure of Soviet society, and the outburst of an anti-religious campaign. All of these created the preconditions, and at the same time laid the foundation of, the Stalin cult. The official celebration of his fiftieth birthday on 21 December 1929 is generally considered one of the opening episodes in the history of the Stalin personality cult (Tucker 1979, 347-366).

The timing of the celebration was appropriate. Lenin had died, Leonid Trotsky had been expelled from the country, and the Left and Right Oppositions had been defeated. However, during the preparations for this important event, there was an annoying glitch from the propaganda machine in Minsk. The Belarusian ideologists made the mistake of ordering the newspapers to publish commemorative materials on the wrong date: on 26 November 1929 (Źviazda 1929, 270, 1). It was corrected on 21, 22 and 23 December, when for three days all Belarusian newspapers published congratulations to the hero of the day on their front pages. The Belarusian ideologists' error had no immediate consequences. In 1929 Stalin's response reflected his studied effort to emulate in public Lenin's example of modestly unassuming behaviour: "I refer your greetings to the working class, who bore and raised me" (Źviazda 1929, 292, 1).

But the man behind the mask of modesty was hungry for adoration. Stalin, as Jerrold M. Post put it, manifested a typically "mirror-hungry" personality, which was attractive to "ideal-hungry" personalities (Post 1993, 99). During the year of his fiftieth birthday celebrations the Belarusian print media started to forge a direct link between him and the common people. Who could forbid the workers, peasants and intellectuals from expressing their feelings about the Party and its leader? The peasants of Polish nationality from the border regions promised him that they would "use all their energy to increase yields" (List sialian-paliakaŭ Stalinu 1929, 1).

At their meeting, Minsk industrial workers decided to give the title of "honourable seamster" to the Secretary General and send him a worker's passbook (Jiašče adna cahlina ŭ spravie industryjalizacyi 1929, 3). The participants of a military exercise conducted in 1929 by the Belarusian Military District sent a message with greetings "to the faithful disciple of Lenin, the leader of the Bolshevik Party, the brother-in-arms during the Civil War" (Hatovy hrudźmi stać na abaronu zavajavańniaŭ Vialikaha Kastryčnika i sacyjalistyčnaha budaŭnictva 1929, 1). And

2 Stalin's takeover of power was reinterpreted in view of this term by American political scientists, especially the historian Robert Tucker. See: Tucker R. C. Stalin in Power - The Revolution from Above. 1929-1941. NY, 1992. 752 pp. 
even Uladzimir Dubouka defended his poem "I Purpuravych Vietraziej Uźvivy" (Duboǔka 1929, 3) from ideologists using Stalin's concept of socialist culture that was 'national by form and proletarian by content', as formulated at the joint Plenum of the All-Union Communist Party Central Committee and Central Control Committee on 23 October 1927 (Stalin 1949, 69).

Although Stalin had won considerable support among the Party functionaries in the post-Lenin years, he never enjoyed popularity comparable to that of the Soviet state's creator. His image was spoiled as a result of forced collectivisation and of the subsequent famine in 1932-1933. Stalin's power was not in danger but nor was it absolute. The establishing of total control over the state required his elevation to Lenin-like eminence in the regime's publicity. The tendency to subsume Lenin's cult entirely into the rising cult of Stalin was in evidence in the joint visualisation of both leaders starting from the early 1930s. Their portraits started to appear next to each other on the front pages of newspapers, on the streets and in offices. In 1931 the assortment of iconic products at the central book store in Minsk was widened and included the new character. Sculptural portraits of Stalin appeared next to display busts of Marx, Engels and Lenin (NARB, f. 4p, vop. 1, spr. 4720, ark. 236).

An important step towards the creation of a "theory of the two leaders" was a celebration of the 60th anniversary of the creator of the Soviet state on 22 April 1930. However, not all local initiatives, as needed and innovative as they were, reached the required support. For example, Stalin ignored a campaign to decorate him with the Order of Lenin launched by TsK KP(b)B Secretary Kanstancin Hiej in Minsk (Źviazda 1930, 132, 2). This and similar actions were supposed to demonstrate Stalin's "modesty” as a part of his public image.

Since the beginning of the 1930s, speeches and articles from Stalin's works were included in programmes of political education at all levels. Thus, they became equal to the works of the "classics" - Marx, Engels and Lenin. Despite the wave of repression against the "national-democrats", in the context of the officially continuing policy of Belarusisation, Stalin's legacy had to be learned by the Belarusians as well as the Belarusian Jews and the Belarusian Poles in their mother's tongue. The first Belarusian translation of one of Stalin's major books, The Questions of Leninism, was drawn into the centre of controversy in 1931. The TsK KP(b)B Department of Propaganda and Agitation banned the Belarusian language version of Questions of Leninism, accusing its translator Jan Hustyr ${ }^{3}$ of political illiteracy as well as of usage of "nationalistic words" like padvojny and kirujučy. Thus, this spectacle of censorship which had broader implications on social media marked the beginning of the wave of Belarusian

3 In January 1934 the Joint State Political Directorate (ADPU) sentenced Jan Hustyr, "the head of the counterrevolutionary organisation, the organizationBelarusian National Centre"," to death and his family was deported from Belarus. 
language Russification which lasted for the entire period of Stalin's rule (NARB, f. 4 p, vop. 1, spr. 5009, ark. 135-139).

Presentation of Stalin as a natural heir of Lenin and his ideology required the glorification of his revolutionary heroic past. Subservient writers falsified actual Party history creating the idealised image of a "die-hard Bolshevik", an image representing Stalin's self-conception. The groundwork of this system of falsification was laid in his letter to the journal Proletarian Revolution which was reprinted in the Belarusian media (Stalin 1931, 2-4). Implications of this document on their work were discussed at hastily convened meetings in the Belarusian Academy of Sciences, Belarusian State University, and of editorial boards. Instructors and students of the Belarusian Communist University even discussed the letter at a special ten-day session (Źviazda 1931, 332, 2). Reports on the proceedings of these meetings show that not only Party historians, but humanities scholars in general, were brought into line with the interpretation of Stalin's letter. All alternative views were stigmatised as "contraband of Trotsky".

The 14th Congress of the All-Union Communist Party which took place in January 1934 is generally considered as a turning point in the cult's evolution (Volkogonov 1996, 343-355). From that time forward, idolatry of Stalin became one of the most important features of communist propaganda. On analysing mass communication in Stalin's Soviet Union, Sarah Davies suggested the use of the term "cult language" (Davis 1997, 178). The name of the dictator used in official discourse needed to be accompanied by epithets praising his genius, wisdom and foresight. Stalin's words were cited and learned by school children and highranking functionaries.

However, such an orgy of personal glorification lacked an emotional or human dimension in the dictator's self-image. The Belarusian Communist Youth newspaper came up with the idea of using the collective reading of Stalin's as an important tool to overcome age differences in daily social life (Rudźko 1934, 2). A Belarusian women's magazine taught readers how to love pravadyr, publishing an interview with his mother Ekaterina Georgievna Dzhugashvili (Hutarka z matkaj tavaryša Stalina 1935, 1). The major Belarusian Communist Party newspaper, Źviazda, described the interior of an exemplary Minsk family housing with the obligatory "portrait of the dearest man on the wall" (Hasman 1936, 4). Belarusian newspaper correspondents shared their impressions of an informal meeting with Stalin in the Kremlin (Kuĺba 1936, 5).

On the other hand, incorrect interpretation of the facts or events related to the dictator, or an error made in the spelling of his name, could be fatal for journalists. For example, on 14 December 1935, a special meeting of TsK KP(b)B Bureau ended with the adoption of the resolution On the distortion of Stalin's name in 
the Ušačy regional newspaper. As a result of its implementation, the Editor of the newspaper was removed from office and placed at the disposal of Soviet Belarus People's Commissar of Internal Affairs Izrail Lieplieŭski (NARB, f. 4p, vop. 1, spr. 7794, ark. 47).

\section{In Literature and Art}

No field of Soviet Belarusian culture was exempt from "finding inspiration" for its activity in Stalin's figure. Poetry, music, theatre, sculpture, painting was used in service of the construction of the personality cult. Many Party ideologists, such as TsK KP(b)B Culture and Propaganda Department chief Aliaksandr Čarnuševič, shared the view that image and allegory could embed an idea of pravadyr in people's consciousness far more easily and more effectively than hours of political education. In his address to the members of an All-Belarusian Party meeting on art issues in December 1931, Čarnuševič articulated the mission of Belarusian art as "to implement the party line" drawn by Stalin (NARB. f. 4p. vop. 1. spr. 5463. ark. 3).

Throughout his reign Stalin showed personal interest in the literary process, interfered in it, and gave it ideological and political dimensions. ${ }^{4}$ Regular reports on the work of newspapers, magazines, publishing houses and writers' organisations were prepared for him by the Central Committee Department of Propaganda and Agitation. Literature in the Soviet culture of the Stalin era occupied a special place and Stalin took charge of it personally. This explains the fact that Soviet literature was chosen as a testing ground for cultural, ideological and organisational innovations before they were transferred to other areas of culture. The General Secretary, as an author of Georgian romantic poetry, understood the significance of national literatures. However, he praised it until the writers and poets tried to tackle the essential issues of national life.

The first Belarusian literary work which praised Stalin was published as a separate edition in 1931 in Minsk. The author of the Asinstan poem was a 25-yearold member of the Belarusian Proletarian and Peasant Writers' Association Ilaryjon Baraška. He wrote the poem for the occasion of the inauguration of a power station near the village of Arechausk, this being the culminating event where the power station was to be named after pravadyr (Baraška 1931, 14).

Socialist realism became Party policy in 1932 when Stalin put into effect the decree On the Reconstruction of Literary and Art Organisations. In February 1933,

4 Filling in the All-Ukrainian Communist Party conference participant's questionnaire in 1920, Stalin wrote "writer (journalist)" in the "profession" column. See Gromov E. Stalin: Iskusstvo i vlast'. M., 2003. S., 72. 
TsK KP(b)B Secretary on ideology Vaclaŭ Žebroŭski explained the basic ideas of the decree to the participants of a meeting specially organised to set up the Union of Soviet Belarusian Writers. Quoting Stalin in his didactic speech, Vaclaŭ Žebroŭski called for the indoctrination of authors and the establishment of control over their output. In their speeches, Janka Kupala and Jakub Kolas supported the concept of socialist realism although they refrained from mentioning the name of pravadyr (Zadačy mastackaj litaratury BSSR 1933, 2). In January 1934, a vow of silence broke young "proletarian poet" Andrej Alieksandrovič, who wrote the poem under the title Song of Proletarian Unity, where each verse ended with an address to pravadyr: "Our dear, beloved Stalin!" (Alieksandrovič 1934, 1).

The new policy was officially declared on the 1st of June 1934 at the first congress of Soviet Belarusian Writers in Minsk. In his opening speech the Head of the TsK KP(b)B Department of Culture and Propaganda of Leninism Dźmitry Konik aggressively and openly demanded that the writers had to translate Stalin's works into literary language. The high-positioned Party propagandist not only theorised about the pravadyr image fictionalisation but artistically interpreted one of the Stalin's speeches himself (Litaratura i mastactva 1934, 38, 2).

In September 1934, shortly after the delegation of the Belarusian writers had come back from the First Congress of Soviet Writers in Moscow, they were invited to a meeting with the TsK KP(b)B First Secretary Mikalaj Hikala. The famine of 1932-33 that had killed over eight million people had just ended and he openheartedly urged the assembly to glorify the values of socialism in an optimistic manner. An important part of his speech was dedicated to the collective letter which the members of the Belarusian delegation to the Congress had sent to Stalin. Although the move was completely loyal to pravadyr, Mikalaj Hikala expressed his concern that it had not been preliminary coordinated with the Party leaders in Minsk. However, all ended well. The collective letter instigators Michaś Lyńkoŭ, Platon Halavač and Michaś Klimkovič were given valuable gifts. The other members of the Soviet Belarusian Writers' Union were presented with a special place to promote Stalin's ideas in literary form: a sanatorium in the town of Puchavičy (NARB, f. 4p, vop. 1, spr. 7614, ark. 9, 11).

At that time, most Belarusian professional writers didn't realise that under the guise of the Soviet Writers' Union they were being drawn into a trap of political and aesthetic control over their creative production. Disobedience meant exclusion from the Union and a virtual ban on publication. The motivation for writers to enter the Union involved a constellation of socialist beliefs, fears of repression, popular values, and closely related material interests. The first works of united writers laid the basis of the Belarusian literary "Staliniana". Kandrat Krapiva identified a "Lenin is Stalin of today" theme in his writing after publishing the verse Who We 
Are Today (Źviazda, 1935, 155, 2). Todar Kliaštorny tried to illustrate the "Belarus is an outpost at the Western borderline of the Motherland" political myth by taking his oath to "the best friend of the Belarusian writers" in his verse New Year's Mood (Rabotnica i kalhaśnica Bielarusi 1936, 1, 1). During the celebrations for the 30th anniversary of one of Janka Kupala's literary works, the poet received a Chevrolet car and cottage on the bank of the Dnieper River as gifts from the government. As a result, at the end of 1935 there had emerged a pseudo-religious Kupala poem in which Stalin was compared to the sun (Litaratura i mastactva 1935, 70, 1).

Visual arts and literature proved among the most efficient tools to market the image of Stalin to the Soviet public. Similar to other fragments of the culture of that day, there was a tendency to centralise all artistic production and interpretation under the control of the state. In 1932 all artists' organisations were abolished and their former members had to work under the aegis of a single Soviet Artists' Union.

Artists learned about the new turn in state cultural politics even earlier on, on 7th December 1931, when a Party meeting on artistic issues took place in Minsk. In their speeches to the meeting the key Party and government officials in charge of culture, with reference to Stalin, justified the centralisation of artistic processes as enabling creative persons to portray the construction of socialism. Representation of pravadyr in art was a subject line of the artists' discussion that followed the official speeches. The newly-appointed head of the Union of Soviet Belarusian Artists organising committee, A. Aranštejn, spoke out against putting Lenin's portraits in gilded rococo frames. Abram Zaboraŭ strongly criticised the idea of displaying busts of Lenin and Stalin along with ballerina statues in the display cases inside one of Minsk's bookstores. The Belarusian-Jewish theatre director Mojše-Arn Rafaĺski informed his audience that Minsk residents could not stop laughing at the monument to Karl Marx for its lack of artistic value (NARB, f. 4p, vop. 1, spr. 5464, ark. 251, 263, 324). As seen from the discussion above, the Party General Secretary was mentioned in the discussion only once, in the context of the representation of other leaders.

The earliest Belarusian sculpture of Stalin was made in 1931 by Abram Brazer. The sculptor tried to obliterate his old passion for impressionism in the new political environment. He submitted his sculpture Stalin on Tribune for the 4th AllBelarusian Art Exhibition but it did not look better than other objects on display by either size or location (Čaćviortaja Ǔsiebielaruskaja mastackaja vystaŭka, pryśviečanaja trecicamu rašajučamu hodu piacihodki 1931, 8-9). The number of Party, state and military leaders' images increased at the Fifth All-Belarusian Art Exhibition in 1932. Among the sculptures of Lenin by Aliaksandr Hrube, the TsK KP(b)B Secretary Vilhieĺm Knoryn by Zair Azhur, and the Belarusian Military District Commander Ijeranim Ubarevič by Abram Brazer, Stalin occupied an 
unpretentious place at the exhibition - in its amateur art section (V Usiebielaruskaja mastackaja vystaŭka 1932, 8-10, 24).

The introduction of images of the leaders of all ranks in public and private spaces legitimised the Soviet state and formed a new collective identity for its citizens. From the beginning, after official declarations of the realistic principles of socialist art, it became obvious that a clear-cut, iconic image of pravadyr ensured its easy understanding and dissemination. Soon after the official opening of the Fifth All-Belarusian Art Exhibition, an art critic Anton Uss instructed 24-year old Zair Azhur with regard to mimesis: "Vilhieĺm Knoryn of yours is not a Party-leader, he looks like an arrogant bourgeois in your interpretation" (Uss 1933, 16).

The future Maître of Belarusian social realism learned quickly. In 1933, after throwing away the "formalism" influence, he started to create the dictator's perfect image of his own. The first Stalin sculpture by Zair Azhur was placed in the newly built Government House in Minsk which was a great success for the young sculptor. Next year he earned commission for a three-metre high statue of Stalin which was installed in the State Library of Soviet Belarus (Azhur 1935, 1). These two works pushed Azhur to the first rank of Soviet sculptors and made him a recipient of numerous titles and awards.

The artist began their Staliniana with a certain delay when the image of the dictator became ubiquitous in propaganda. In 1935 the first graphic portrait of pravadyr by Valianćin Volkaŭ was published in the New Year issue of the Belarusian creative intellectuals' newspaper (Litaratura i mastactva 1935, 36, 1). However, by that time there was a large volume of copied images of Stalin, created by Russian artists.

In January 1935 the chair of the Soviet Belarus Council of People's Commissars, Mikalaj Haladzied, addressing the participants of the 11th All-Belarusian Congress of Soviets, sharply criticised Mikalaj Husieŭ, a graphic artist from the state publishing house. He cited in particular a Stalin portrait which had been created by Mikalaj Husieŭ and reproduced for distribution, describing it as "an enemy sortie" (Nilski 1935, 1). This episode was perhaps the most telling example of Soviet Belarusian art censorship as well as the making of Stalin's iconography.

As it is now known, a set of canonical representations of pravadyr, a warrior, a father, an architect of socialism, was orchestrated by the dictator himself. However, Stalin was much more than the sole authoritative voice on all art products, he became, as Anita Pisch put it, "art's principle subject matter" and, by the mid-1930s, public space was saturated with all kinds of Stalin images (Pisch 2016, 92). 


\section{Topographic Staliniana}

Stalin's ambitions became evident to the political environment even before the official inauguration of his cult during his 50th birthday on 21 December 1929. As early as July 1929, Stalin instructed his secretary, Aleksandr Poskrebyshev, "to respond positively in the future" to all workers' requests to name factories, railway stations or similar buildings in his honour (Devlin 2009, 222). During Stalin's 50th anniversary celebration dozens of industrial enterprises, collective farms and communes were given his name. The biggest printing house in Minsk became the first enterprise in the city to bear his name. In 1929, agricultural communes named after Stalin appeared in Parycki rajon, Babrujskaja akruha, Drysienski rajon, Polackaja akruha, Loźnienski rajon and Viciebskaja akruha. The year after that, in Viciebsk rajon, the name of pravadyr was given to the biggest collective farm (Chalavin 1930, 3).

An important toponymic innovation occurred in Orsha rajon shortly after the construction of a local power station. The power station near the village of Arechausk was an integral part of Lenin's GOERLO electrification plan implementation and the Belarusian authorities decided to turn it into the symbol of the republic's industrial modernisation. On 1 January 1929, Chairman of the Soviet Belarus Central Executive Committee Aliaksandr Čarviakoŭ sent a telegram to Stalin and informed him that the 10th anniversary of the republic's formation had been marked by giving the dictator's name to the first Belarusian regional power station. The telegram ended with the words: "Long live the Bolshevik guard and Lenin's best follower - comrade Stalin" (NARB, f. 6, vop. 1, spr. 1976, ark. 2). Journalists who covered the opening ceremony of the power station named after Stalin invented the new geographic name "Stalinstan" to represent the site of construction with the village adjoining it. It might be suggested that this neologism derived from the city of Stalingrad where, by 1929, this experiment in socialist urban development was in full swing.

In September 1931, Stalin's name was given to a flax plant in the city of Škłoŭ which was widely publicised as another symbol of socialist industrialisation. New socialist labour was personalised there not only in the name of the plant itself. The most productively effective workers' teams (two-thirds of the total number of employed workers were women) were given the name of Stalin (Žuraŭliova 1932, 12).

The overwhelming majority of communist agitators exploited archaic features of the Belarusian mentality such as widespread belief in miracles. One of the "miracles" caused by toponymic innovation was documented by The Belarusian Young Communists newspaper Čyrvonaja Źmiena in March 1930. The newspaper journalist wrote the story of a Jewish collective farm (kolkhoz) organised at the old 
estate of Bahrynava Talačynski rajon in 1927 and ruined purposely by anonymous enemies. Everything changed in 1930, after newly-appointed collective farm Chair Aron Minaker suggested naming the lagging enterprise after Stalin. Then the economic indicators improved so dramatically that the Belarusian peasants from neighbouring villages "doubted the claim of the Jewish hog's weighing a thousand pounds" (Krasucki 1930, 30).

In most cases, the dictator's name was irrelevant to the economic effectiveness of a collective farm or industrial enterprise. In 1932 there was a mass exit of peasants from the collective farm bearing the name Stalin's Grain Grower. One of the former collective farmers Fiodar Lempicki explained his decision to leave, saying: "My life was better before the kolkhoz, now I work a lot and get little. There's no paid sick leave. There's no chance for a better life for those who will stay in kolkhoz" (NARB, f. 4p, vop. 1, spr. 5570, ark. 36). Things went wrong at the pig-breeding farm named after Stalin in Slutsk rajon (Ab rabocie partyjnych jačejek kolhasu «Proletary» Kapyĺskaha r-nu i kolhasu imia Stalina Sluckaha r-nu 1933, 2). In addition, due to unfavourable working conditions and staffing problems, it was impossible to organise a normal production process in a Mahilieu leather factory named after Stalin (NARB, f. 4p, vop. 1, spr. 6059, ark. 24). Such cases undermined the solemnity of the places and facilities named after Stalin.

In 1935 health and living conditions at the social settlement for workers of a glass plant named after Stalin in the city of Homel failed to meet elementary standards. Unmarried women and men lived in the same barracks, families with children shared their rooms with unmarried workers, and children did not attend school due to a lack of clothing and shoes. After harsh criticism of the plant management by the Party leadership, the regional office of the People's Commissariat of Internal Affairs (Narodny Kamisaryjat Unutranych Spraŭ, NKUS) came up with a quick solution to all of these domestic problems: they revealed a "counter-revolutionary fascist organisation" consisting of 14 people, mostly from the management of the plant unit. Another 200 "elements with unreliable class background" were urgently removed from the enterprise soon afterwards. These social purges turned out differently from what NKUS had intended and actually led to disorganisation of the production process. Finally, a case was fabricated against the plant Director, who was then dismissed from his job and expelled from the Party (NARB, f. 4p, vop. 1, spr. 8987, ark. 5-17).

One could not only be honoured by the name of pravadyr, but equally be punished by being denied the right to bear it. At the end of 1929 such a punishment was imposed on a machine-building plant in the city of Babrujsk. Local authorities explained to the plant workers and administrative staff that they had been penalised "for mismanagement, chaotic accounting, but mostly for low productivity". 
Throughout the following year, 1930, the workers and administrators of the Babrujsk machine-building plant worked hard and had regained the name of Stalin by the end of it (A. M. 1931, 3).

During the 1930s, the number of Stalin-originated toponyms continued to grow steadily. The dictator's name was given to a gas turbine plant in Babrujsk, a small village in Dziaržynsk rajon, a district of the Belarusian capital, a housing office in Homel, and several others. Stalin's name was actively used by ideologists as a mobilisation tool during the first five-year plans. They organised a competition among Belarusian industrial enterprises and their production teams, where they competed for the privilege of bearing the name of Stalin. By 1935 there were 56 such "Stalin's production teams" which numbered a total of 723 of the most productive workers (udarniki) in Soviet Belarus (Harelik 1935, 4). The best Belarusian Railway train women's crew was distinguished by being given Stalin's name as well (P. D. 1934, 10). Źviazda newspaper journalist Vasil Parchimovič tried to engage readers as well as demonstrate his loyalty to pravadyr by choosing the pen name "Stalnou".

Parallel to the efforts to make the name of Stalin omnipresent in social and even private life, the names of his closest followers, teachers of his message, the "twelve apostles", were introduced into the Belarusian public mind. After prominent Bolshevik leader Sergei Kirov was killed by a gunman at his Leningrad office in 1934, Stalin escalated the repressions against dissident elements of the Party, this culminating in the Great Purge of the late 1930s. The Kirov victimisation campaign should have helped win mass support for the new wave of repressions. Memorialisation of the murdered Leningrad leader in the Soviet topographical space was an integral part of his victimisation. In 1934, the name of Sergei Kirov was given to the Kamunar plant, Dynama stadium, Communist Institute of Journalism, school No. 4 and Univiersiteckaja vulica in Minsk; to the Čyrvony mietalist plant, Vakzalnaja vulica and to the Pedagogical Institute in Viciebsk; to the Praletar plant and Forest Institute in Homiel; to an auto repair plant in Mahilieu; and to a matchstick factory in Barysaŭ. By the end of the year a new locality named after Kirov appeared in Babrujsk rajon (Uviekaviečym pamiać S. M. Kirava 1934, 4).

Living Party leaders had been commemorated in Soviet Belarus as well. By mid-1930s the topographical cult of the Civil War hero and Stalin's close friend Klim Voroshilov was successfully exported there. One of Minsk's city districts, the Red Army House (Dom Čyrvonaj Armii), as well as many collective farms and sport facilities, proudly adopted the name of the People's Commissar of Defence. Lazar Kaganovich was commemorated as an outstanding Belarusian revolutionary in Homiel. A shoe factory in Minsk, a flax plant in Viciebsk and agricultural machinery plant in Homiel were named after "iron Lazar". The other members of 
the dictator's inner circle were also represented in urban infrastructure. There was the woodworking factory named after Vyacheslav Molotov in Minsk, the theatre named after Michail Kalinin located in the town of Rečyca, among others.

\section{Cult Fighters}

The legitimacy of Stalin's regime depended not only on positive support from the public, but also on the fear of repressions which kept dissenters from going into opposition, thus risking punitive sanction or worse. Stalin was an attentive reader of Machiavelli who warned rulers that they should seek to be loved and feared, but in cases of needing to choose one of the two, fear was the choice to be made (Rees $2004,8)$. Among those who refrained from using the language of worship quite a few, lacking an instinct for self-preservation, riskily expressed criticism of Stalin publicly.

Lean Trotsky and the Left Opposition demonstrated a strong capacity to resist the rising cult of Stalin. As it well known, inner-Party struggle reached its peak in November 1927 when the leaders of the "bol'sheviki-lenintsy" block, Leonid Trotsky and Grigory Zinovyev, were expelled from the Communist party. The Left Opposition leaders organised secret meetings, printing houses, counterdemonstrations and organisational structures that attacked the bureaucratic degeneration of the Party. These events were echoed in the cities of Soviet Belarus, where the tradition of socialist movements and trade-unionism were not dead yet.

The celebration of the 10th anniversary of the October Revolution accompanied a number of protest actions in several Belarusian cities. The protests were triggered by the publication of a large portrait of Stalin on the Źviazda newspaper anniversary issue front page (Źviazda 1927, 253, 1). On 7 November 1927, an opposition group in Mogilev distributed leaflets calling on the boycott of decisions of the Party Central Committee. An alternative workers' rally was organised by the leftist group in Homiel on that day (NARB, f. 4p, vop. 1, spr. 3091, ark. 382, 530). The official October Day celebration planned in the town of Suraž was disrupted by P. Vašukievič, a worker who fiercely criticised bureaucratisation and the violation of workers' democratic rights. He ended the speech by publicly calling Stalin a "bastard" (NARB, f. 15p, vop. 4, spr. 254, ark. 105-109). Among those who supported the Left Opposition were servicemen of the Belarusian Military District who perceived Trotsky as one of creators of the Red Army and a victor in the Civil War. One of the most important voices of dissent in the Belarusian Military District belonged to the Commander of the Cavalry Brigade, hero of the Civil War, Michaił Ziuk. In 1927 he publicly criticised the political commissars, the Party Central Committee and Stalin personally (NARB, f. 15p, vop. 4, spr. 252, ark. 109). 
Trotsky's ideas found strong support among the younger generation, especially the Komsomol which was seen as "the Party barometer" by the principal Stalin opponents. On the other hand, the immediate outcomes of the revolution from above caused grievances and criticism among youth. In the late 1920s and early 1930s, an overwhelming majority of young people in the Komsomol, enthusiastic and loyal to Stalin, got rid of a tiny minority who voiced their discontent with the dictatorship.

The transformation of the Left Opposition into a few illegal groups led to the radicalisation of their activities. As a result, the State Political Directorate (DPU) started active surveillance on the youth Trotskyist underground groups, monitoring their communication and mobility. The young Trotskyist leaders continued to fight for a better future for all in contrast with their Komsomol political opponents preoccupied with building their careers.

On 11 May 1931, Belarusian DPU Secret Police Deputy Chief Jan Hrodzis reported an underground youth Trotskyist group activity in the town of Červien to TsK KP(b)B. The group's leader, 27-year-old Lazar Trachtenbierh, an articulate critic of Stalin's rule, particularly concerned the DPU. Under his leadership, the group members had developed a code for correspondence, conspiratorial aliases, held daily meetings in the woods where they discussed issues such as weapons acquisition, new members' recruitment, and even implantation of their men into the DPU structure. However, subversive pamphlets were seen by the young Trotskyists as the most effective weapon against dictatorship. The following leaflets were printed and distributed by them in Červień: An appeal to the peasantry, Against the existing Party leadership, A letter to Stalin. The latter is worth quoting, since it exemplified a typical opinion of the opposition-minded Soviet Belarusian youth.

\section{Mr. Stalin!}

You have the nerve to call comrade Trotsky 'Mister' and we have the courage to declare that 'Mister' is you, as Trotsky is our comrade. You are leading the proletariat and peasants blindly, zig-zagging back and forth. Your vaunted industrialisation and collectivisation rest on the administrative scourge. Neither class stratum of the country supports your policy. You say that you are fulfilling Lenin's will. Then why don't you make his will regarding yourself. Why don't you admit the mistakes, especially in national issues? Moreover, you are using the Party bureaucracy and DPU to clamp professional revolutionary and all working people's mouths shut. You are a monarch, as the Politburo dominated by the secretariat and the secretariat is in your hands. If you cannot lead the working class along Lenin's path, give 
us a chance to rule and we will ensure the victory of socialism in the country. Long live Lenin's policy and its defender comrade Trotsky!

Leninists group (NARB, f. 4p, vop. 1, spr. 4720, ark. 239-242)

On 16 May 1931, the DPU arrested the members of the Červien young Trotskyists group. The punishment for them was relatively mild. Lazar Trachtenbierh was detained in a 'political isolator'. The other group members went into exile.

In the early 1930s the DPU, helped by a vast army of informers in factories, government offices, and the Red Army, crushed the Left Opposition. In December 1932, a "counter-revolutionary group" consisting of nine civil servants, including the former Chairman of the City Council F. Viršyc, was discovered in the city of Mazyr (NARB, f. 15p, vop. 4, spr. 510, ark. 3). An underground Trotskyist post-graduate student group at the Belarusian Academy of Sciences was arrested that year (NARB, f. 60p, vop. 3, spr. 533, ark. 14). As a result of the party purge performed by the order of Stalin during 1933, the number of Belarusian communists decreased from 54,392 to 37,653. Of these, 715 (7.5\%) were expelled as principal opponents to Stalin's regime or "Trotskyists" (Ancipaŭ 1934, 23).

Once Trotsky was out of the way and the Left Opposition had been made illegal, Stalin side-lined and removed Nikolai Bukharin and his Right Opposition allies from important positions. In Soviet Belarus, where there was no evident support for the Right Opposition, national-oriented intellectuals arrested for belonging to the DPU-fabricated "Union for the Liberation of Belarus" were declared right oppositionists. For example, one of the "union" members, Aliaksandr Anichoŭski, a teacher, was charged with insulting pravadyr, whom he allegedly called "sergeant" (NARB, f. 4p, vop. 1, spr. 4720, ark. 23). Among the fabricated allegations made against Masiej Siadnioŭ, as defined by the DPU investigator, was the attribution of the words "Stalin is a bad theorist and tongue-tied speaker" to the writer (Na sud historyi. Uspaminy, dyjalohi 1994, 223). In 1932, Viciebsk Machinebuilding Institute students openly disagreed with what they considered a Stalinist falsification of the Marxist thesis of the right of nations to self-determination. They interrupted the study of one of the dictator's speeches in a political science class with the following statements: "Soviet Belarus totally depends on Moscow", "the self-determination of Soviet Belarus is a comedy", and "Stalin forces the Belarusian government to export thousands of tons of food products to Moscow and Leningrad" (NARB, f. 4p, vop. 1, spr. 6096, ark. 24).

The first five-year plan transformed many aspects of Soviet Belarusian society. The way of life for the majority changed drastically over this period. Thousands of peasants, whose property and entire villages were incorporated into the state economy, migrated to the cities. The inter-Party struggle didn't mean much to the 
newly-recruited and poorly-educated industrial workers. The low wages, high prices for essential products, and the low quality of food products were issues of prime importance which provoked spontaneous reactions. All the sentiments of a protest character were meticulously recorded by DPU agents. One such incident of "disorderly behaviour" was reported in 1932 on a Viciebsk construction site's eatery where taskmaster Harjunoŭ threw a bowl of porridge, saying: "Take it to Stalin, maybe he will understand something" (Dziaržaŭny archiŭ Minskaj voblaści (DAMV), f. 164, vop. 1, spr. 132, ark. 201).

All the accidental or deliberate cases of damage to, and destruction of, Stalin's portraits were immediately reported by local authorities to the DPU offices. The most radical form of "iconoclasm" was the burning of the dictator's image, an action which was rooted in the ancient Slavs' practice of the deliverance from danger by fire (Narodnaya demonologiya Poles'ya 2012, 398). The members of Baĺšavik collective farm in the Čarnicki village Soviet in the Lioźnienski region secretly took the portrait of Stalin out of the village council and burned it in the nearby forest. After the peasants had been arrested, they explained their actions as follows: "We burned him because he hadn't given bread to us" (NARB, f. 4p, vop. 1, spr. 11867, ark. 28). The members of the Soviet of the village collective farm named after K. Voroshilov Samachvalavicki in the Minski region took revenge on Stalin by gouging out the eyes on his portrait (NARB, f. 4p, vop. 1, spr. 12099, ark. 132). Belarusian high school students in the town of Dubroŭna performed a similar act (NARB, f. 4p, vop. 1, spr. 13803, ark. 50). The arrest and subsequent execution of Soviet Belarus Council of People's Commissars Deputy Chair Ivan Žuraŭlioŭ in 1938 came as a delayed reaction to his "non-punishment of the son of the merchant who shot a gun at Stalin's portrait” (NARB, f. 4p, vop. 1, spr. 10970, ark. 64).

Passive forms of resistance to the rising cult of Stalin drew the attention of the political police secondarily. However, non-violent resistance was also dangerous to the totalitarian system. "Weapons of the weak" were not allowed to actively oppose the Stalinist propaganda, but demonstrated people's everyday refusal to accept the terms of their subordination. One of the important forms of passive resistance to the dictator's cult was rumour which, as T. Johnston demonstrated it, was an integral part of the Soviet identity (Johnston 2011, 21). As an important part of everyday life, rumours were the source of information alternative to the official propaganda. Some rumours which were spread about Stalin reflected the hidden desire to be free from tyranny and were the subject of special attention from the DPU.

In the spring of 1932, a rumour circulated in Žlobin rajon. "Voroshilov shot Stalin," it claimed, "who wanted to flee abroad, Stalin is in the hospital now" (NARB, f. 4p, vop. 1, spr. 6059, ark. 5). Soon political police officers were informed of a rumour circulating in Miechaŭski rajon that "There is no Stalin in 
Moscow, Krupskaya runs things for him" (NARB, f. 4p, vop. 1, spr. 10668, ark. 27). The new 1936 Soviet Constitution gave people hope that the authoritarian Stalin's rule could be softened: "Trotsky arrived in Moscow and, according to the new constitution, he will be elected to the government of the USSR" (NARB, f. 4p, vop. 1, spr. 10668, ark. 107).

\section{Conclusion}

Throughout the historical period under discussion, by using print media, visual art, oral propaganda and topography, Stalin successfully transformed his dull, bureaucratic image of administrator to that of the saviour of the Soviet nation. Cult products manufactured by the combined efforts of the Belarusian Party ideologists and journalists, artists, and poets revealed ambitions, desires, uncertainties and fears surrounding the construction of authoritarian rule. The important parts of the personality cult were myths, rituals and the use of special language which were key factors to creating a mental image of authoritarian rule. They were indicators of full membership of the society, involvement in the construction of Socialism and political loyalty to the regime. The cult also supposed to mobilise and distract the masses from the ongoing terror of the purges and the oppression of any kind of opposition or difference in opinions. It was the basis of power relationships in Stalin-era Belarus, and a locomotive of the dictatorship.

A great number of members of the atomised Soviet Belarusian society responded to the myth of Stalin with adulation and devotion. Various psychological and sociocultural motivations lay behind its creation and growth. For example, many young Belarusian technicians and writers, teachers and doctors, after dizzying careers in the early 1930s, were heartily enchanted by the myth of pravadyr. However, the study of archival sources points to its mixed reception in the population at large. The cult of personality was strongly opposed by the Left Opposition. It couldn't be accepted by national-oriented intellectuals. Resistance and blind obedience were not the only two optional forms of totalitarian thought patterns, which also included various forms of adaptation and survival strategies. Men and women, old and young, townspeople and villagers, Belarusians and Jews, Poles and Tatars perceived Stalin's cult differently. The cult perception of the Belarusians, who predominantly still lived in pre-modern conditions, was childlike in its sincerity. However, in comparison with Moscow or Tbilisi, it was more restrained in its external manifestations.

Stalin's cult of personality formed within the confines of the broader Soviet society-building project which was based on paternalistic, illiberal and authoritarian values. The elimination of wealthy peasants, merchants and intellectuals in 
combination with rapid urbanisation (which, in fact, was the "ruralisation" of urban areas) and mass media emergence made possible the rise of the cult of pravadyr. It might be suggested that Stalin created a new form of traditionalism to secure his unlimited power. The cult of personality, during its formative stages in the second half of the 1920s and in the first half of the 1930s, led to a celebration of the dictator and his personal glorification in the year when the "Stalin Constitution" of 1936 was adopted. By that time, the cult of personality had become an essential part of Soviet Belarusian political culture. 


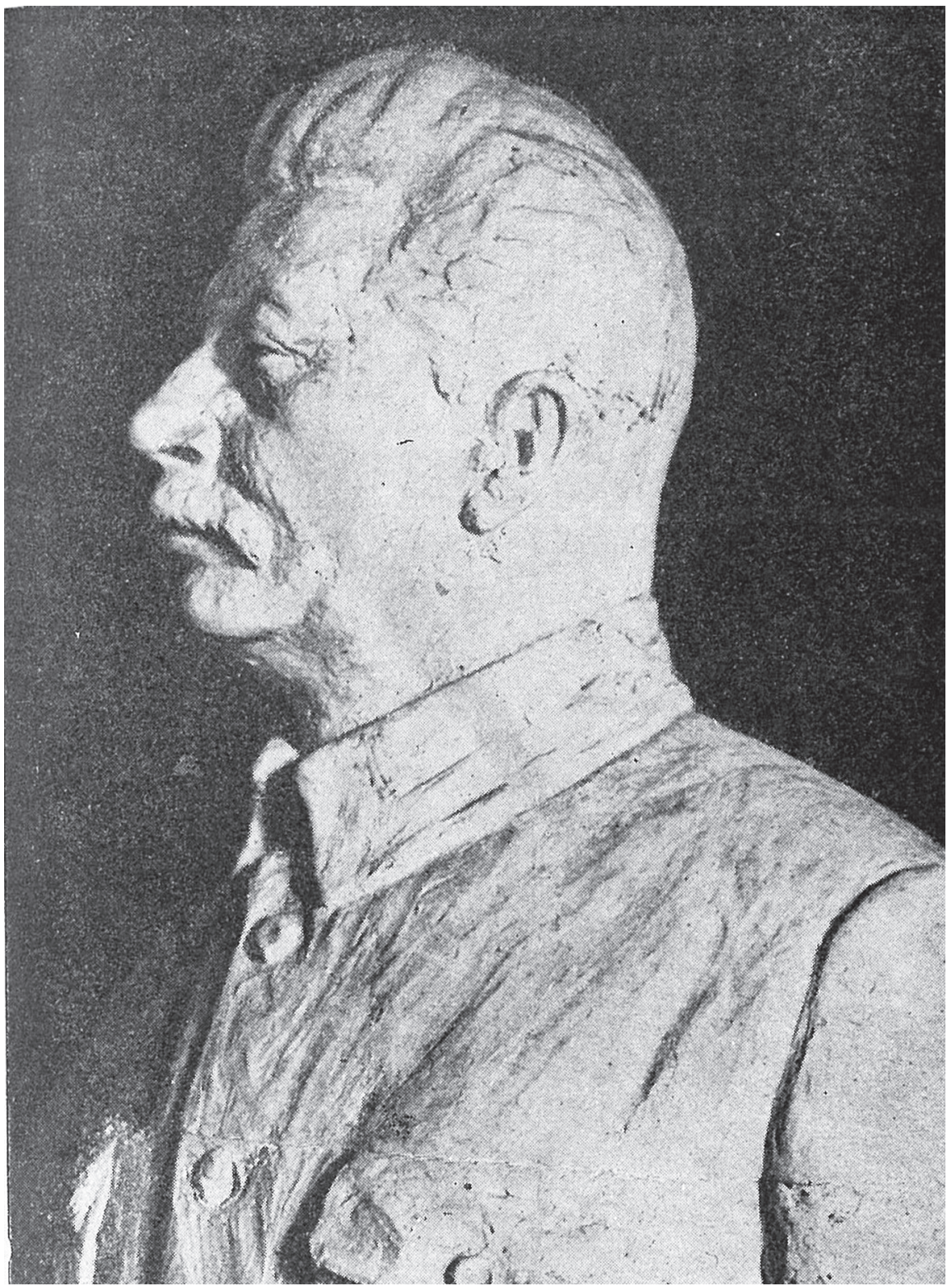

Figure 2: Abram Brazer. "Stalin at the tribune". Alabaster, 1931. For the first time it was demonstrated at the IV All-Belarusian arts exhibition.

The IV All-Belarusian arts exhibition dedicated to the third decisive year of the Five-Year Plan: Maliarstva. Skulptura. Graphika: [Catalogue]. Mn., 1931. 


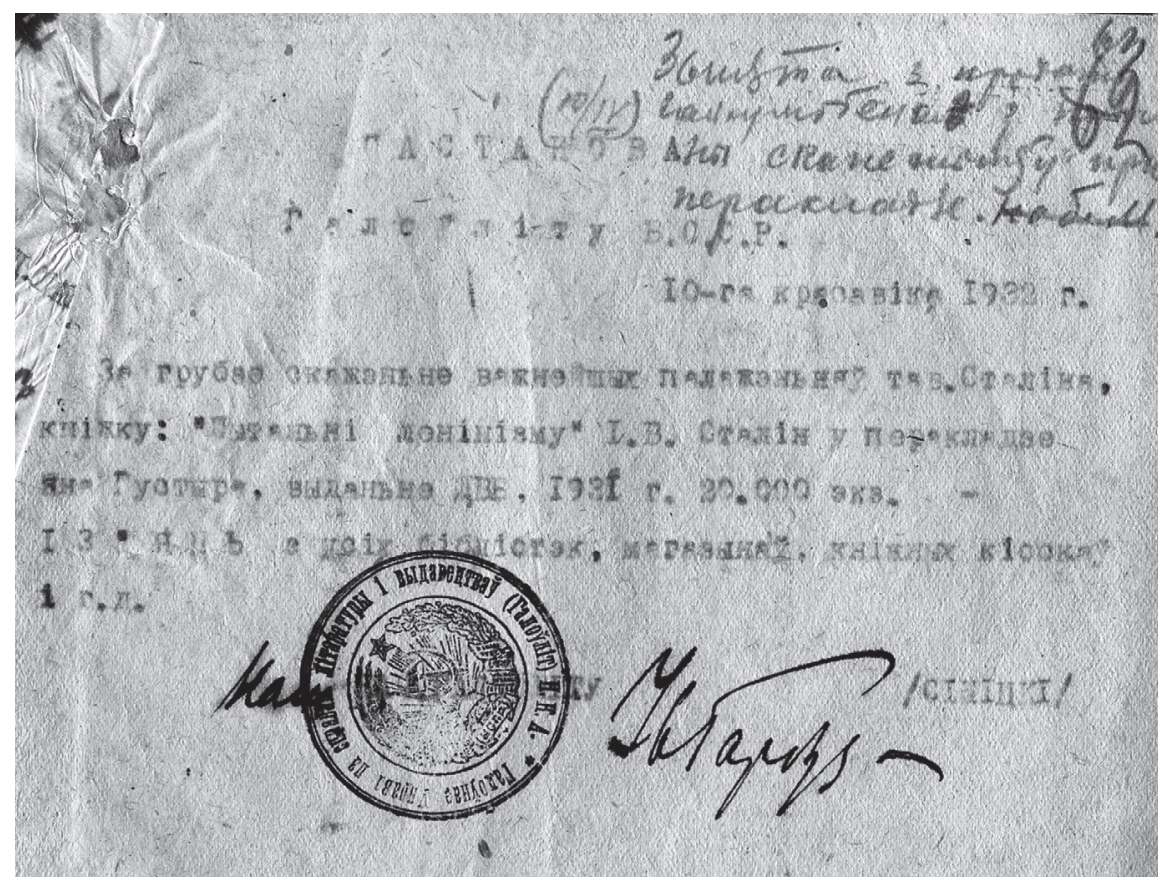

Figure 3: The Decision of the Haloylit of the BSSR from 10 April 1932 about the receipt of the Belarusian translation of the book "The questions of Leninism" written by Stalin. NARB. F. 4p. Vop. 1. Spr. 5452. Ark. 62. 


\section{References}

\section{Archival Collections}

Dziaržaŭny archiŭ Minskaj voblaści (DAMV).

164, vop. 1, spr. 132, ark. 201.

Nacyjanaĺny archiŭ Respubliki Bielaruś (NARB).

f. 4p, vop. 1, spr, 1983, ark, 40.

f. 4 p, vop. 1, spr. 3091, ark. 382, 530.

f. 4 p, vop. 1, spr. 4720, ark. 23, 236, 239-242.

f. 4p, vop. 1, spr. 5009, ark. 135-139.

f. 4 p. vop. 1. spr. 5463. ark. 3.

f. 4p, vop. 1, spr. 5464, ark. 251, 263, 324.

f. 4 p, vop. 1 , spr. 5570, ark. 36 .

f. 4p, vop. 1, spr. 6059, ark. 5, 24.

f. 4 p, vop. 1, spr. 6096, ark. 24.

f. 4p, vop. 1, spr. 7614, ark. 9, 11 .

f. 4p, vop. 1, spr. 7794, ark. 47.

f. 4 p, vop. 1, spr. 8987, ark. 5-17.

f. 4p, vop. 1, spr. 10668, ark. 27, 107.

f. 4 p, vop. 1, spr. 10865, ark. 5 .

f. 4p, vop. 1, spr. 10970, ark. 64 .

f. 4 p, vop. 1, spr. 11867, ark. 28 .

f. 4p, vop. 1, spr. 12099, ark. 132.

f. 4 p, vop. 1, spr. 12948, ark. 159 .

f. 4 p, vop. 1, spr. 13803, ark. 50 .

f. 6, vop. 1, spr. 1976, ark. 2.

f. 15 p, vop. 4 , spr. 252, ark. 109 .

f. 15p, vop. 4, spr. 254, ark. 105-109.

f. 15 p, vop. 4 , spr. 510, ark. 3 .

f. 60 p, vop. 3 , spr. 533, ark. 14 . 


\section{Secondary Sources}

Ab rabocie partyjnych jačejek kolhasu «Proletary» Kapyĺskaha r-nu i kolhasu imia

Stalina Sluckaha r-nu, Čyrvonaja źmiena, 1933, 85, s. 2.

Ashirova, A., 2009. Stalinismus und Stalin-Kult in Zentralasien. Turkmenistan 1924-1953. Stuttgart and Hannover: Ibidem-Verlag.

Alieksandrovič, A., 1934. Pieśnia prolietarskaha jadnańnia, Litaratura i mastactva, 3, s. 1 .

A. M., 1931. Stalincy pieramahli, Źviazda, 5, s. 3.

Ancipaŭ, N., 1934. Itohi čystki KP(b)B. Mensk: BDV.

Azhur, Z., 1935. Ad 1934 da 1935 hoda, Litaratura i mastactva, 1, s. 1.

Baraška, I., 1931. Asinstan. Narys. Mensk: BDV.

Chalavin, 1930. Kalhas imia Stalina dapamahaje malamocnym haspadarkam, Źviazda, 110, s. 3.

Čaćviortaja Ǔsiebielaruskaja mastackaja vystaŭka, pryśviečanaja treciamu rašajuamu hodu piacihodki, 1931. Mensk: BDV.

Davis, S., 1997. Popular Opinion in Stalin's Russia. Terror, Propaganda and Dissent, 1934-1941. New York: Cambridge University Press.

Derman, J., 2012. Max Weber in Politics and Social Thought. From Charisma to Canonization. New York: Cambridge University Press.

Devlin, J., 2009. Mif o Staline: razvitie kul’ta, Trudy «Russkoy Antropologicheskoy shkoly», 6, s. 222.

Duboŭka, U., 1929. Rastlumačeńnie (Zamiest listu ŭ redakcyju), Źviazda, 75, s. 3. Ennker, B., 1998. Politische Herrschaft und Stalinkult, 1929-1939, in S. Plaggenborg, Stalinismus. Neue Forschungen und Konzepte. Berlin: Verlag Arno Spitz GmbH. ss. 151- 182.

Friedrich, C., Brzezinski, Z., 1965. Totalitarian Dictatorship and Autocracy. Cambridge (Mass.): Harvard university press.

Gill, G., 1980. The Soviet leader cult: reflections on the structure of leadership in the Soviet Union, British Journal of Political Science, 10, pp. 167-86.

Harelik, 1935, Zliot udarnikaŭ stalinskich bryhad, Źviazda, 101, s. 4.

Hasman, N., 1936. Radasna spatkajem śviata, Źviazda, 245, s. 4.

Hatovy hrudźmi stać na abaronu zavajavańniaŭ Vialikaha Kastrynika i sacyjalistynaha budaŭnictva, 1929, Źviazda, 220, s. 1. 
Hutarka z matkaj tavaryša Stalina, 1935, Rabotnica i kalhaśnica Bielarusi, 20, s. 1. Jašče adna cahlina ŭ spravie industryjalizacyi, 1929, Źviazda, 159, s. 3.

Johnston, T., 2011. Being Soviet. Identity, Rumour, and Everyday Life under Stalin 1939-1953. Oxford: Oxford University Press.

Kelly, C., 2005. Riding the magic carpet: children and leader cult in the Stalin era, The Slavic and East European Journal, 49, pp. 199-224.

Kostyuk, M., 2002. Bol'shevistskaya sistema vlasti v Belarusi. Moskva: Institut rossiyskoy istorii RAN.

Krasucki, J., 1930. Adzin z mnohich. Pra kolhas imia Stalina ŭ Taločynskim rajonie, Čyrvonaja źmiena, 75, s. 3.

Kulba, K., 1936. Jak ja havaryla z tavaryšom Stalinym, Rabotnica i kathaśnica Biełarusi, 2, s. 5.

List sialian-paliakaŭ Stalinu, 1929, Źviazda, 55, s. 1.

Litaratura i mastactva, 1934, 38, s. 2.

Litaratura i mastactva, 1935, 36, s. 1 .

Litaratura i mastactva, 1935, 70, s. 1 .

Morgan, K., 2017. International communism and the cult of the individual: leaders, tribunes and martyrs under Lenin and Stalin. London: Palgrave Macmillan.

Moscovici, S., 2011. Vek tolp. Istorichesky traktat po psikhologii mass. Moskva: Akademichesky proekt.

Barys Sačanka, ed. 1994. Na sud historyi. Uspaminy, dyjalohi. Minsk: Mastackaja litaratura.

Vinogradova, L., and Levkievskaya, E., eds. 2012. Narodnaya demonologiya Poles 'ya. Vol. II. Demonologizatsiya umershikh lyudey. Moskva: Rukopisnye pamyatniki Drevney Rusi.

Nilski, 1935. Trackiscka-zinoŭjeŭski vyradak vykinut z partyi, Litaratura $i$ mastactva, 11, s. 1.

P. D., 1934. Druhi rejs, Rabotnica i kalhaśnica Bielarusi, 13, s. 10.

Pisch, A., 2016. The Personality Cult of Stalin in Soviet Posters. 1929-1953. Canberra: ANU Press.

Plamper, J., 2010. Alkhimiya vlasti. Kul't Stalina v izobrazitel'nom iskusstve. Moskva: Novoje litjeraturnoje obozrjenije.

Platonaŭ, R., 1996. Palityki. Idei. Liosy. Hramadzianskija pazicyi va ŭmovach 
narastańnia ideolaha-palityčnaha dyktatu ŭ Bielarusi 20-30-ch hadoŭ. Minsk: BielNDIDAS.

Politichesky otchet TsK - Doklad t. Stalina, 1925, Mahilioŭski sielanin, 67, s. 1.

Post, J. M., 1993. Current concepts of the narcissistic personality: implications for political psychology, Political Psychology, 14, pp. 99-121.

Prot'ko, T., 2002. Stanovlenie sovetskoy totalitarnoy sistemy v Belarusi (19171941 gg.). Minsk: Tesey.

Rabotnica i kalhaśnica Biełarusi, 1936, 1, s. 1.

Rees, A., 2004a. Leader Cults: Varieties, Preconditions and Functtions, in B. Apor, eds. The leader cult in communist dictatorships. NY: Palgrave Macmillan. pp. 3-28.

Rees, A., 2004b. Political Thought from Machiavelli to Stalin: Revolutionary Machiavellism. Basingstoke: Palgrave Macmillan.

Rolf, M., 2004. Working Towards the Centre: Leader Cults and Spatial Politics in Pre-war Stalinism', in B. Apor, eds. The leader cult in communist dictatorships. NY: Palgrave Macmillan. pp. 141-160.

Rudźko, J., 1934. Škola lia miažy, Čyrvonaja źmiena, 48, s. 2.

Sobanet, A., 2018. Generation Stalin: French writers, the fatherland, and the cult of personality. Bloomington: Indiana University Press.

Stalin, J., 1931. Ab niekatorych pytańniach historyi baĺšavizmu. Piśmo ŭ redakcyju žurnau "Proletarskaja rjevoliucija”, Čyrvonaja Bielaruś, 22-23, ss. 2-4.

Stalin, J., 1949. Sochinenija. Vol. 10. Moskva: OGIZ.

Stepper, B. and Suppan, A., 2000. «Revolyutsiya sverkhu» i kul’t Stalina, in B. V. Nosov, ed. Slavyanskie narody: obshchnost' istorii i kul'tury: K 70-letiyu chlena-korrespondenta Rossiyskoy akademii nauk Vladimira Konstantinovicha Volkova. Moskva: Indrik. ss. 286-305.

Trotsky, L., 1990. Stalin: V 2 t. Vol. 2. Moskva: Terra.

Tucker, R., 1979. The Rise of Stalin's Personality Cult, American historical Review, 84, pp. 347-366.

Uss, A., 1933. Piataja Usiebielaruskaja mastackaja vystaŭka, Mastactva $i$ revaliucyja, 1-2, s. 16.

Uviekavičym pamiać S. M. Kirava, 1934, Čyrvonaja źmiena, 266, s. 4.

Zadačy mastackaj litaratury BSSR, 1933, Čyrvonaja źmiena, 70, s. 2. 
Źviazda, 1927, 253, s. 1.

Źviazda, 1929, 270, s. 1.

Źviazda, 1929, 292, s. 1.

Źviazda, 1930, 132, s. 2.

Źviazda, 1931, 332, s. 2.

Źviazda, 1935, 155, s. 2.

Žuraŭliova, V., 1932. Masavaja praca na iĺnozavodzie imia Stalina (Škloŭski rajon), Rabotnica i kalhaśnica Bielarusi, 9, s. 12.

V Usiebielaruskaja mastackaja vystaŭka. 1932, Mensk: BDV.

Volkogonov, D., 1996. Stalin: V 2 kn. Kn. 1. Moskva: Novosti. 